\title{
AN ALTERNATIVE APPROACH ON BIOREMEDIATION OF HEAVY METALS IN TANNERY EFFLUENTS WASTE USING STREPTOMYCES SP.
}

\author{
THIRUMURUGAN D ${ }^{1 *}$, IBRAHIM ADAMU KARFI ${ }^{2}$, VIJAYAKUMAR R ${ }^{3}$, NITHYA TG ${ }^{4}$
}

${ }^{1}$ Department of Biotechnology, Faculty of Science and Humanities, SRM University, Chennai, Tamil Nadu, India. ${ }^{2}$ Department of Microbiology, Kano University of Science and Technology Wudil, Nigeria. ${ }^{3}$ Department of Microbiology, Bharathidasan University Constituent College, Perambalur, Tiruchirappalli, Tamil Nadu, India. ${ }^{4}$ Department of Biotechnology.

Email: microthiru08@gmail.com

Received: 01 May 2017, Revised and Accepted: 04 June 2017

\section{ABSTRACT}

Objective: The present study is conducted to investigate the abilities of microorganisms to degrade heavy metals in industrial tannery effluent sample.

Methods: Tannery effluent sample was collected from effluent treatment plant and analyzed for physicochemical parameters. The potential microbes were isolated and identified by morphological and biochemical characterization. The sample was analyzed before and after to assess the heavy metal reducing the ability of the microorganism and the respective percentage of reduction were studied using X-ray fluorescence spectrometry.

Results: The samples were initially found to be highly contaminated with chromium, nickel, and cadmium. Out of three potential isolates, the isolate Streptomyces sp. was found to exhibit a better reduction against chromium (25.7\%), cadmium (14.6\%), and nickel (23.1\%) in 50 ppm at longer incubation period. Comparatively, the reduction abilities of all the three isolates against all the three heavy metals increased with the increase in the incubation period but decreased with the increase in initial metal ion concentration except in the case of Streptomyces sp. against nickel where the reducing ability increased with the increase in metal concentration.

Conclusion: Apparently, the present study revealed that Streptomyces sp. had a better remediation potential than the indigenous Pseudomonas sp. and Aspergillus sp. Ultimately, the finding of this research has shown that the Streptomyces sp. can be used as a potent bioremediation agent for treating tannery and industrial effluent in an eco-friendly process.

Keywords: Bioremediation, Tannery effluent, Heavy metals, Streptomyces sp.

(C) 2017 The Authors. Published by Innovare Academic Sciences Pvt Ltd. This is an open access article under the CC BY license (http://creativecommons. org/licenses/by/4. 0/) DOI: http://dx.doi.org/10.22159/ajpcr.2017.v10i10.19480

\section{INTRODUCTION}

Across the world, pollution is rapidly increasing due to variations in both natural and anthropogenic activities as well as controlled and uncontrolled release of solid and liquid wastes. Use of chemical fertilizers, explosives, and tar are some of the major reasons for increased contaminants such as heavy metals, organic, and inorganic compounds in the biosphere. Furthermore, industries such as textiles, electroplating, and tanneries are recognized as a serious environmental threat all over the globe [1]. These effluents possess toxic chemicals such as sulfides, chromium salts, and heavy metals that can change effluents into poisonous waste water [2,3]. Heavy metals are roughly defined as elements having a density above $6 \mathrm{~g} / \mathrm{cm}^{3}$. Among these elements, $\mathrm{Co}, \mathrm{Cu}, \mathrm{Mn}, \mathrm{Ni}, \mathrm{Se}$, and $\mathrm{Zn}$ are important only in trace amounts [4]. Whereas higher levels cause severe damage to the environment $[5,6]$. The effluents are densely colored and foul-smelling liquids with high concentrations of chemical oxygen demand (COD), biochemical oxygen demand (BOD), and dissolved solids. Most heavy metals such as $\mathrm{Co}, \mathrm{Cr}, \mathrm{Cu}, \mathrm{Pb}$, and $\mathrm{Cd}$ are recorded to be present in complex form [7] and have become a menace when subjected to removal. Traditional chemical methods used for cleaning effluent pollutants usually remove symbiotic microbial biota which is a major adverse effect [8]. Hence, natural processes to break down the accumulated pollutants using biological system are currently used by researchers [9]. Recent fundamental work has revealed the existence of numerous ranges of microorganisms exhibiting prominent levels of bioremediation activities [10]. Group of microbial flora such as bacteria, fungi, actinobacteria, and algae has been reported to perform various bioremediation processes under favorable conditions [11]. From the past decades, actinobacteria are recognized as extremely promising agent of potent bioactive compounds that are being relatively utilized for various commercial applications. Comparatively, actinobacteria are illustrious for their ability to produce numerous secondary metabolites, and till date, it remains matchless [12]. Although physical and chemical methods are widely used, they are less effective with high cost and have limited application [13]. During physical and chemical treatment process, massive amount of sludge is formed which is highly toxic and poses difficulty in safe disposal [14]. Microbial degradation has been reported effective in the remediation of effluents in certain quantities with reduced cost using indigenous microorganisms. The present study is to identify the indigenous microorganisms present in the tannery effluent and also to screen their bioremediation potential in removal of chromium, cadmium, and nickel present in the tannery and industrial effluents which are discarded into the environment without any treatment. Simultaneously, a comparative study was made using actinobacteria from marine soil as a source for bioremediation and their pertaining activities.

\section{METHODS}

Study area

For the isolation of microorganism in the present study, Sample-I (effluent) was collected from effluent treatment plant (PTIET Co., Ltd.) at Pallavaram, Chennai, Tamil Nadu. Sample-II (soil) was collected from Muttukadu backwater (near South Chennai, Tamil Nadu) which extends for a distance of $20 \mathrm{~km}$ from the mouth of the estuary.

\section{Collection of samples}

$1 \mathrm{~L}$ of tannery effluent sample was procured from a combined effluent treatment plant at Pallavaram, Chennai (India), in sterile specimen 
bottles and transported to the laboratory in an ice pack. One of the bottles was acidified with concentrated nitric acid to bring down $\mathrm{pH}$ up to 2.0 , while the other bottle was stored at $40^{\circ} \mathrm{C}$ to arrest any biological activity.

\section{Analysis of physicochemical parameters}

Several physicochemical parameters on tannery effluent sample were performed for determination of temperature, color, smell, pH, COD, and BOD. All the tests were performed according to standard methods [15].

\section{Heavy metal analysis in effluent}

A suitable volume of effluent was taken and filtered through Whatman No.1 filter paper, and $\mathrm{pH}$ was adjusted using weak base $\left(\mathrm{Na}_{2} \mathrm{CO}_{3}\right)$ to 7.0. The sample was analyzed for heavy metal concentration by X-ray fluorescence (XRF) spectrometry (using minipal 4 bench top model) as described by Zarazua et al. [16]

\section{Isolation of microorganisms}

The collected effluent samples were directly used for isolation of bacteria and fungi. The sample was serially diluted and spread over the surface of nutrient agar (NA) and potato dextrose agar (PDA) plates without addition of metal and incubated. The marine soil samples were serially diluted and streaked on starch casein agar (SCA) amended with $50 \mathrm{mg} / \mathrm{ml}$ of fluconazole at $\mathrm{pH} 7.5$ to inhibit fungal contaminates. Then, all the plates were kept at $28^{\circ} \mathrm{C}$ for $7-10$ days.

\section{Screening of potential isolates Primary screening}

The morphologically different isolates were inoculated on NA, PDA, and SCA (for actinobacteria) medium amended with $\mathrm{Cr}^{+6}, \mathrm{Cd}^{+2}$, and $\mathrm{Ni}^{+2} 50 \mathrm{mg} / \mathrm{L}$ concentration (i.e., $\mathrm{K}_{2} \mathrm{Cr}_{2} \mathrm{O}_{7}, \mathrm{CdCO}_{3}$, and $\mathrm{Nicl}_{2}$ ) and incubated at appropriate condition. Finally, all the isolates were characterized using morphological and biochemical methods.

\section{Secondary screening}

To determine heavy metal depletion ability of various isolates, a stock metal solution of $\mathrm{Cr}^{+6}, \mathrm{Cd}^{+2}$, and $\mathrm{Ni}^{+2}$ were prepared by dissolving ARgrade salt sources such as $\mathrm{K}_{2} \mathrm{Cr}_{2} 0_{7}$, $\mathrm{CdCO}_{3}$, and $\mathrm{Nicl}_{2}$ in sterile distilled water. Working metal solution was then prepared using the stock solution for concentration of $50 \mathrm{ppm}(2,500 \mathrm{cps}), 100 \mathrm{ppm}$ (5,000 cps), and $150 \mathrm{ppm}$ $(7500 \mathrm{cps})$ for each of the above metal. Three different concentrations $(50,100$, and $150 \mathrm{ppm})$ of heavy metals in the working solution were prepared in NA, SDA, and SCA for bacteria, fungi, and actinobacteria, respectively. A loop full of log phase culture was inoculated into the appropriate amended medium in $100 \mathrm{ml}$ Erlenmeyer's flask. The inoculated flasks were incubated in rotary shaker at $120 \mathrm{rpm}$ with $32^{\circ} \mathrm{C}$ for $72-144 \mathrm{hrs}$ for bacteria and $120 \mathrm{rpm}$ with $27^{\circ} \mathrm{C}$ for $6-10$ days for fungi and actinobacteria. $10 \mathrm{ml}$ of each was taken after the end of incubation period and adjusted to $\mathrm{pH}$ 7.0. The heavy metal reduction analysis was carried out using XRF spectrometry as described by standard method [16,17]. The concentration of metal left in solution was recorded at $3^{\text {rd }}$ and $6^{\text {th }}$ day, $6^{\text {th }}$ and $9^{\text {th }}$ day, and $10^{\text {th }}$ and $13^{\text {th }}$ day of bacteria, fungi, and actinobacteria inoculated broth, respectively.

\section{RESULTS AND DISCUSSION}

Physical character of the effluent sample such as color, odor, $\mathrm{pH}$, and temperature was analyzed. The effluent appeared black in color with foul smell, and the $\mathrm{pH}$ was recorded as 8.75 with temperature of $29^{\circ} \mathrm{C}$. Color is the primary contaminant to be recognized in textile industry waste due to the presence of unused dye in water, which affects esthetic as well as biological activity of the ecosystem [18]. The data revealed high BOD (1200 mg/L) and COD (3800 mg/L) of the effluent were found to have exceeded the Tamil Nadu Pollution Control Board (TNPCB) standard, which may be due to high content of organic pollutant in the effluent. Similar finding was conducted and reported that BOD and COD values were very higher than permissible limit of TNPCB [19]. The most potential isolates were identified as Pseudomonas sp., Aspergillus sp., and Streptomyces sp. by characterization studies.

\section{Heavy metal analysis}

The heavy metal characterization and quantification from the tannery effluent sample were determined using XRF spectrometry (Fig. 1). The tannery effluent sample was analyzed for the presence of three heavy metals such as $\mathrm{Cr}$, Cd, and $\mathrm{Ni}$ and it contains $\mathrm{Cr} 24.11$ cps, Ni 396.30 cps, and $\mathrm{Cd} 4,990.81$. The measurement was conducted in triplicate to minimize error, and mean values were recorded. All the concentrations were beyond the permissible limit of TNPCB. Similar study has been carried out and reported that the effluent was found to contain heavy metals such as $\mathrm{Mn}, \mathrm{Cr}, \mathrm{Pb}$, and $\mathrm{Zn}$ were beyond the permissible limit $[20,21]$.

\section{Isolation of indigenous microorganisms}

A total of 99 bacterial isolates were isolated from tannery effluent, and among this, five morphologically different isolates were identified. From the five morphologically different isolates, the most potential bacterial isolate was obtained through a repeated sub culturing on respective media amended with $50 \mathrm{ppm}(2500 \mathrm{cps})$ concentration of $\mathrm{Cr}^{+6}$ at $37^{\circ} \mathrm{C}$ for $48 \mathrm{hrs}$. The most potential isolate showed Gram-negative, rod shaped with positive reaction against indole, methyl red, Voges-Proskauer, citrate, catalase, and oxidase and $\mathrm{Ak} / \mathrm{Ak}$ reaction in triple sugar iron test. Based on the morphological and biochemical reaction, the most potential isolate was identified as Pseudomonas sp. Similarly, the previous study also reported that the genus Pseudomonas has high potential to remove $\mathrm{Cr}^{+6}(\mathrm{VI})$ [22]. Eight fungal species were observed in PDA medium. Among eight morphologically different isolates, only four of them that had metal-resistant abilities. Among the 4 potential isolates, the most resistant isolate was identified as Aspergillus sp. with lactophenol cotton blue stain followed by microscopic examination as described in "Hand book of soil Fungi" by Nagamani et al. [23]. A total of 14 actinobacterial isolates were isolated from 5 different sampling stations. Four isolates showed potential-resistant activity against heavy metals. The most potential isolates produced powdery graycolored aerial spore mass, brown-colored reverse side on SCA medium, respectively. The isolate showed spirally twisted sporophore with 2-3 bends, globose shaped with smooth spores surface. It produced a positive reaction against catalase, amylase, and oxidase. Based on the morphological and biochemical reactions, the most potential isolate was identified as Streptomyces sp. All the most potent isolates from three groups were selected for secondary screening (bioremediation activity).

\section{Uptake of heavy metals by bacteria}

The most potential bacterial isolate Pseudomonas sp. degrade the metals $\mathrm{Cr}^{+6}$ at $3^{\text {rd }}$ day of incubation was $23.3 \%$ (in $50 \mathrm{ppm}$ ), $19.4 \%$ (in $100 \mathrm{ppm}$ ), and $6.7 \%$ (in $150 \mathrm{ppm}$ ); however, in the $6^{\text {th }}$ day, it uptakes $28.4 \%$ (in $50 \mathrm{ppm}$ ), 20.2\% (in $100 \mathrm{ppm}$ ), and $7.8 \%$ (in $150 \mathrm{ppm}$ ). The percentage of $\mathrm{Ni}^{+2}$ uptake on $3^{\text {rd }}$ day was 4.4 (in $50 \mathrm{ppm}$ ), 4.1 (in $100 \mathrm{ppm}$ ), and 0.5 (in $150 \mathrm{ppm}$ ), but at the $6^{\text {th }}$ day, the percentage of uptake was $11.9 \%$ (in $50 \mathrm{ppm}$ ), $12.1 \%$ (in $100 \mathrm{ppm}$ ), and $20.4 \%$ (in $150 \mathrm{ppm}$ ). As for $\mathrm{Cd}^{+2}$ on $3^{\text {rd }}$ day, percentage uptake was 9.0 (in 100 ppm), 7.7 (in 150 ppm), and 7.5 (in 200 ppm); however, at the $6^{\text {th }}$ day, it was $14.0 \%$ (in $100 \mathrm{ppm}$ ), $18.5 \%$ (in $150 \mathrm{ppm}$ ), and $10.8 \%$ (in $200 \mathrm{ppm}$ ). For all metals, the percentage of reduction increases with increase of incubation period and it decreases when concentration of metal increased (Table 1). Comparatively, in this study, Pseudomonas sp. was found to reduce better $\mathrm{Cr}>\mathrm{Ni}>\mathrm{Cd}$ all in 6 days of incubation. Similar finding was conducted by Karmakar and Ray [24]. The study reported that a Gram-negative bacteria isolated from tannery soil reduced $\mathrm{Cr}$ (vi) ranging from 100 to $500 \mathrm{mg} /$ at $35 \%$ within $72 \mathrm{hrs}$ at pH 6 and temperature $37^{\circ} \mathrm{C}$.

\section{Uptake of heavy metals by fungal isolate}

The potential fungal isolate Aspergillus sp. percentage of uptake of $\mathrm{Cr}^{+6}$ at $6^{\text {th }}$ day was $11.2 \%$ (in $50 \mathrm{ppm}$ ), $3.2 \%$ (in $100 \mathrm{ppm}$ ), and $2.9 \%$ (in $150 \mathrm{ppm}$ ). However, at the $9^{\text {th }}$ day of incubation, it was $11.5 \%$ (in $50 \mathrm{ppm}$ ), $12.8 \%$ (100 ppm), and $3.1 \%$ (in $150 \mathrm{ppm}$ ). For $\mathrm{Ni}^{+2}$ at the $6^{\text {th }}$ day, percentage uptake was 4.8 (in $50 \mathrm{ppm}$ ), 2.6 (in $100 \mathrm{ppm}$ ), and 1.2 (in $150 \mathrm{ppm}$ ), but at the $9^{\text {th }}$ day, it was $12.7 \%$ (in $50 \mathrm{ppm}$ ), $17.3 \%$ (in 


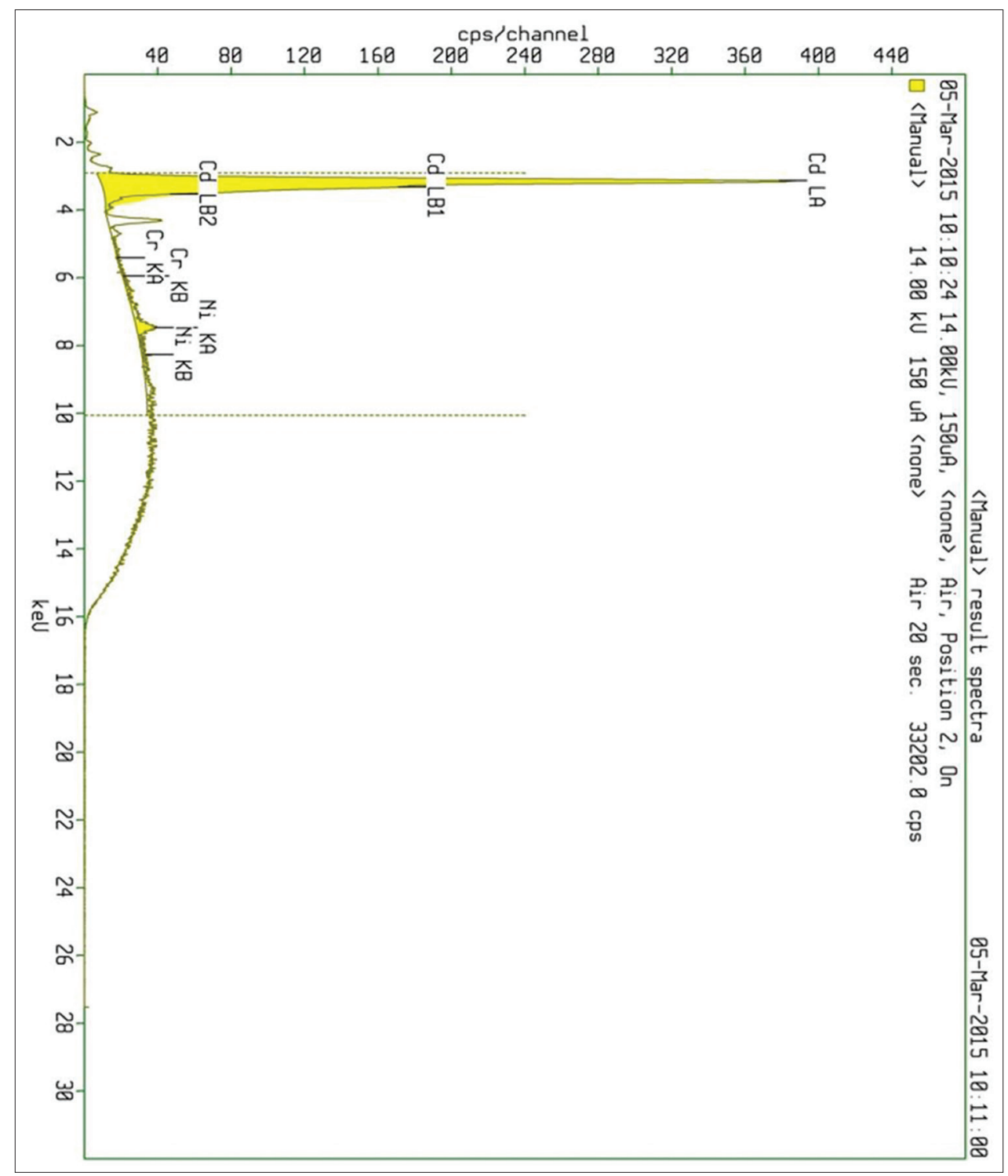

Fig. 1: X-ray fluorescence spectrometry analysis of tannery effluent sample

Table 1: Percentage of uptake of chromium, nickel, and cadmium in broth by bacterial isolate

\begin{tabular}{llll}
\hline $\begin{array}{l}\text { Heavy } \\
\text { metal }\end{array}$ & $\begin{array}{l}\text { Concentration } \\
\text { in cps } / \mathbf{p p m}\end{array}$ & $\begin{array}{l}\text { Percentage of } \\
\text { uptake in } \mathbf{3}^{\text {rd }} \text { day }\end{array}$ & $\begin{array}{l}\text { Percentage of } \\
\text { uptake in } \mathbf{6}^{\text {th }} \text { day }\end{array}$ \\
\hline $\mathrm{Cr}^{+6}$ & $2500 / 50$ & 23.3 & 28.4 \\
& $5000 / 100$ & 19.4 & 20.2 \\
& $7500 / 150$ & 6.7 & 7.8 \\
$\mathrm{Ni}^{+2}$ & $2500 / 50$ & 4.4 & 11.9 \\
& $5000 / 100$ & 4.1 & 12.1 \\
& $7500 / 150$ & 0.5 & 26.4 \\
$\mathrm{Cd}^{+2}$ & $5000 / 100$ & 9.0 & 14.0 \\
& $7500 / 150$ & 7.7 & 18.5 \\
& $10,000 / 200$ & 7.5 & 10.8 \\
\hline
\end{tabular}

$100 \mathrm{ppm}$ ), and $6.7 \%$ (in $150 \mathrm{ppm}$ ). For $\mathrm{Cd}^{+2}$ at the $6^{\text {th }}$ day, percentage uptake was 8.7 (in $100 \mathrm{ppm}$ ), 6.8 (in $150 \mathrm{ppm}$ ), and 1.9 (200 ppm), but at the $9^{\text {th }}$ day, it was $24.1 \%$ (in $100 \mathrm{ppm}$ ), $18.8 \%$ (in $150 \mathrm{ppm}$ ), and $18.8 \%$ (in $200 \mathrm{ppm}$ ). Therefore, the result revealed that there was increase in reduction of metals with increase in incubation period while increase in concentration caused decrease in metal reduction ability of the isolate (Table 2). Substantial number of studies had revealed similar results as reported by Han et al. [25], although there was little variation in $\mathrm{pH}$ and temperature under study.

\section{Uptake of heavy metals by Streptomyces sp.}

After incubation at ambient condition, the Streptomyces sp. percentage of uptake of $\mathrm{Cr}^{+6}$ at the $10^{\text {th }}$ day was $21.4 \%$ (in $50 \mathrm{ppm}$ ), $16.3 \%$ (in $100 \mathrm{ppm}$ ), and $8.0 \%$ (in $150 \mathrm{ppm}$ ), but at $13^{\text {th }}$ day, it was $25.7 \%$ (in $50 \mathrm{ppm}$ ), $18.9 \%$ (in $100 \mathrm{ppm}$ ), and $9.8 \%$ (in $150 \mathrm{ppm}$ ). $\mathrm{For} \mathrm{Ni}^{+2}$, the percentage of uptake at $10^{\text {th }}$ day was 4.0 (in $50 \mathrm{ppm}$ ), 7.7 (in $100 \mathrm{ppm}$ ), and 20.3 (in $150 \mathrm{ppm}$ ), but at the $13^{\text {th }}$ day, it was $14.6 \%$ (in $50 \mathrm{ppm}$ ), $23.1 \%$ (in $100 \mathrm{ppm}$ ), and $21.3 \%$ (in $150 \mathrm{ppm}$ ). Similarly, for $\mathrm{Cd}^{+6}$ at the $10^{\text {th }}$ day, the percentage of uptake was 2.9 (in $100 \mathrm{ppm}$ ), 2.4 (in $150 \mathrm{ppm}$ ), and 2.0 (in $200 \mathrm{ppm}$ ), but at the $13^{\text {th }}$ day of incubation, the percentage of uptake was 23.5 (in $100 \mathrm{ppm}$ ), 20.6 (in $150 \mathrm{ppm}$ ), and 19.8 (in $200 \mathrm{ppm}$ ). The result so far had shown an increase in the uptake of all the three metals along increase in the incubation period and also a decrease in the uptake ability as metal concentration increased except in $\mathrm{Ni}^{+2}$. The percentage uptake of $\mathrm{Ni}^{+2}$ increased when concentration increased (Table 3). Similar studies were reported on the ability of Streptomyces sp. to degrade heavy metals as reported by El Baz et al. [26]. The present study revealed that marine Streptomyces sp. has shown a good potentiality in bioremediation of heavy metals. Significant 
Table 2: Percentage of uptake of chromium, nickel, and cadmium in broth by fungal isolate

\begin{tabular}{llll}
\hline $\begin{array}{l}\text { Heavy } \\
\text { metal }\end{array}$ & $\begin{array}{l}\text { Concentration } \\
\text { cps } / \mathbf{p p m}\end{array}$ & $\begin{array}{l}\text { Percentage of } \\
\text { uptake in } \mathbf{6}^{\text {th }} \text { day }\end{array}$ & $\begin{array}{l}\text { Percentage of } \\
\text { uptake in } \mathbf{9}^{\text {th }} \text { day }\end{array}$ \\
\hline $\mathrm{Cr}^{+6}$ & $2500 / 50$ & 11.2 & 11.5 \\
& $5000 / 100$ & 3.2 & 12.8 \\
& $7500 / 150$ & 2.9 & 3.1 \\
$\mathrm{Ni}^{+2}$ & $2500 / 50$ & 4.8 & 12.7 \\
& $5000 / 100$ & 2.6 & 17.3 \\
& $7500 / 150$ & 1.2 & 6.7 \\
$\mathrm{Cd}^{+2}$ & $5000 / 100$ & 8.7 & 24.1 \\
& $7500 / 150$ & 6.8 & 18.8 \\
& $10000 / 200$ & 1.9 & 20.8 \\
\hline
\end{tabular}

Table 3: Percentage of uptake of chromium, nickel, and cadmium in broth by actinobacteria

\begin{tabular}{llll}
\hline $\begin{array}{l}\text { Heavy } \\
\text { metal }\end{array}$ & $\begin{array}{l}\text { Concentration } \\
\text { in cps } / \mathbf{p p m}\end{array}$ & $\begin{array}{l}\text { Percentage of } \\
\text { uptake in } \mathbf{1 0}^{\text {th }} \text { day }\end{array}$ & $\begin{array}{l}\text { Percentage of } \\
\text { uptake in } \mathbf{1 3}^{\text {th }} \text { day }\end{array}$ \\
\hline $\mathrm{Cr}^{+6}$ & $2500 / 50$ & 21.4 & 25.7 \\
& $5000 / 100$ & 16.3 & 18.9 \\
& $75000 / 150$ & 8.0 & 9.8 \\
$\mathrm{Ni}^{+2}$ & $2500 / 50$ & 4.0 & 14.6 \\
& $5000 / 100$ & 7.7 & 23.1 \\
& $7500 / 150$ & 20.3 & 21.3 \\
$\mathrm{Cd}^{+2}$ & $5000 / 100$ & 2.9 & 23.1 \\
& $7500 / 150$ & 2.4 & 20.6 \\
& $10000 / 200$ & 2.0 & 19.8 \\
\hline
\end{tabular}

reduction was recorded in bacterial isolate, especially on chromium (VI) at lower concentrations. Comparatively, in the degradation process of $\mathrm{Ni}$ and $\mathrm{Cd}$, Streptomyces sp. was found to be more efficient than the indigenous Pseudomonas sp. and Aspergillus sp.

\section{CONCLUSION}

In the present study, a group of metal tolerant bacteria, fungi, and actinobacteria was isolated, identified, and utilized for biosorption of multimetal contaminated effluent. Bioremediation capabilities of all the isolates decreased with increase in the initial metal concentrations except in nickel reduction by Streptomyces sp. Thus, it is highly evident that metal decontamination by actinobacteria could be a suitable alternative approach to reduce metal content in a significant and costeffective method.

\section{ACKNOWLEDGMENTS}

The authors are thankful to the Management of SRM University, India, for providing necessary facilities.

\section{REFERENCES}

1. Tariq SR, Shah MH, Shaheen N, Khalique A, Manzoor S, Jaffar M. Multivariate analysis of selected metals in tannery effluents and related soil. J Hazard Mater 2005;122(1-2):17-22.

2. McMullan G, Meehan C, Conneely A, Kirby N, Robinson T, Nigam P, et al. Microbial decolourisation and degradation of textile dyes. Appl Microbiol Biotechnol 2001;56(1-2):81-7.

3. Apte AD, Verma S, Tare V, Bose P. Oxidation of $\mathrm{Cr}(\mathrm{III})$ in tannery sludge to $\mathrm{Cr}(\mathrm{VI})$ : Field observations and theoretical assessment.
J Hazard Mater 2005;121(1-3):215-22.

4. Bruins MR, Kapil S, Oehime FW. Microbial resistance to metals in the environment. Ecotoxicol Environ Saf 2000;45(3):198-207.

5. Hare L. Aquatic insects and trace metals: Bioavailability, bioaccumulation, and toxicity. Crit Rev Toxicol 1992;22(5-6):327-69.

6. Lenart A, Wolny-Koladka K. The effect of heavy metal concentration and soil $\mathrm{pH}$ on the abundance of selected microbial groups within ArcelorMittal Poland steelworks in Cracow. Bull Environ Contam Toxicol 2013;90(1):85-90.

7. Chibuike GU, Obiora SC. Heavy metal polluted soils: Effect on plants and bioremediation methods. Appl Environ Soil Sci 2014;14:1-12.

8. Chaudry MA, Ahmad S, Malik MT. Supported liquid membrane technique applicability for removal of chromium from tannery wastes. Waste Manage 1997;17(4):211-8.

9. Sarkar B. Heavy Metals in the Environment. New York: Marcel Dekker; 2002.

10. Leena R, Raj DS. Biodecolourization of textile effluent containing reactive back-B by effluent adapted and non adapted bacteria. Afr J Biotechnol 2008;7(18):3309-13.

11. Olukanni OO, Osuntoki AA, Gabriele GO. Textile effluent biodegradation potentials of textiles effluent-adapted and non-adapted bacteria. Afr J Biotechnol 2006;5:80-4.

12. Thirumurugan D, Sankari D, Vijayakumar R. Screening of chitinase production and antifungal activity of Streptomyces sp. Act7 from East Coast Region, South India. Int J Pharm Pharm Sci 2015;7(5):38-41.

13. Chen KC, Huang WT, Wu JY, Houng JY. Microbial decolorization of azo dyes by Proteus mirabilis. J Ind Microbiol Biotechnol 1999;23(1):686-90.

14. Puvaneswari N, Muthukrishnan J, Gunasekaran P. Toxicity assessment and microbial degradation of azo dyes. Indian J Exp Biol 2006;44(8):618-26.

15. American Public Health Association. Standard Methods for the Examination of Water and Waste Water. $20^{\text {th }}$ ed. New York, Washington, DC: American Public Health Association; 1998

16. Zarazua G, Giron-Romero K, Tejeda S, Leon CC, Avila-Perez P. Total reflection $\mathrm{X}$-ray fluorescence analysis of toxic metals in fish tissues. Am J Anal Chem 2014;5:805-11.

17. Christopher M, Cournoyer B, Nesma X. Novel telluride amended media and specific chromosomal and Ti plasmid probes for direct analysis of soil populations of Agrobacterium biovar 1 and 2. Appl Environ Microbiol 2001;67:65-74.

18. Thirumurugan D, Vijayakumar R. Investigation of physico-chemical properties of rhizosphere sediments from East Coast region, Tamil Nadu, India. Int J Pharm Pharm Sci 2015;8(2):332-4.

19. Banat IM, Nigam P, Singh D, Marchant R. Microbial decolorization of textile dye containing effluents: A review. Bioresour Technol 1996;58(3):217-27.

20. Chowdhury M, Mostafa MG. Treatment of leather industrial effluents by filtration and coagulation processes. Water Resour Ind 2013;3:11-22.

21. Panda SS, Sahoo K, Muduli SD, Sahoo G, Ahemad MD, Nayak BB, et al. Chromium tolerant indigenous fungal strains from industrial effluents of Anugul district, Odisha. J Biol Life Sci 2014;2(2):634-40.

22. Deepali D. Bioremediation of chromium (Vi) from textile industry's effluent and contaminated soil using Pseudomonas putida. Iran J Energy Environ 2011;2(1):24-31.

23. Nagamani A, Kunwar IK, Manoharachary C. Handbook of Soil Fungi. New Delhi: I K International Publishing House; 2006.

24. Karmakar M, Ray RR. Characterization of hexavalent chromium reducing bacterial strain isolated from tannery effluents of Kolkata. Int J Pharm Biol Arch 2013;4:337-41.

25. Han R, Li F, Liu T, Li X, Wu Y, Wang Y, et al. Effects of incubation conditions on $\mathrm{Cr}(\mathrm{VI})$ reduction by c-type cytochromes in intact Shewanella oneidensis MR-1 cells. Front Microbiol 2016;7:732-46.

26. El Baz S, Baz M, Barakate M, Hassani L, El Gharmali A, Imziln B. Resistance to and accumulation of heavy metals by actinobacteria isolated from abandoned mining areas. Sci World J 2015;15:1-12. 